\title{
Kajian Penerapan Fondasi Sumuran Pada Jembatan Pombeve di Kabupaten Sigi Sulawesi Tengah
}

\author{
G.J. Padondan ${ }^{a}$ dan S. Ramadhania* \\ a Jurusan Teknik Sipil, Fakultas Teknik Universitas Tadulako, Palu \\ ${ }^{*}$ Corresponding author's e-mail: sriyatiramadhani@gmail.com
}

Received: 18 August 2020; revised: 28 August 2020; accepted: 30 August 2020

\begin{abstract}
The Pombeve Bridge is a bridge that connects both villages Pombeve and Sidera in the terms of public transportation and the economic interests. The purpose of this research is to re-analyze the bearing capacity of the caisson foundation based on the value of the Standard Penetration Test (SPT). The Pombeve Bridge has a span of $50 \mathrm{~m}$ by using caisson foundation in a depth of $4 \mathrm{~m}$. The data used for analysis are secondary data obtained from PT. Citra Komunikasi Perkasa. The analysis results show that the bearing capacity of the caissons for loads working along the abutment is $\mathrm{P}=8536.52 \mathrm{kN}$ with a caisson diameter of $3 \mathrm{~m}$ and a depth of $4 \mathrm{~m}$, hence, it is obtained that $\mathrm{Qg}=12051.32 \mathrm{kN}>\mathrm{P}=8536.52 \mathrm{kN}$. The foundation stability calculation of the horizontal load on the abutment shows that $\Sigma \mathrm{H}=$ $7662,117 \mathrm{kN}>$ than the horizontal load that works along the abutment which is $\Sigma T y=964,180 \mathrm{kN}$. Meanwhile, the settlement calculation of a single caisson foundation on the abutment is $\mathrm{S}=130.008 \mathrm{~mm}$, where the settlement that occured meets the $<$ Sijin requirements of 250 $\mathrm{mm}$.
\end{abstract}

Keywords: Caisson, SPT, bearing capacity, sattlement

\begin{abstract}
Abstrak: Jembatan Pombeve merupakan jembatan yang menghubungkan Desa Pombeve dan Desa Sidera dalam segi transportasi umum maupun kepentingan perekonomian. Tujuan dari penelitian ini adalah untuk menganalisis kembali kapasitas dukung fondasi sumuran berdasarkan nilai Uji Penetrasi Standar (SPT). Jembatan Pombeve mempunyai bentang $50 \mathrm{~m}$ dengan menggunakan fondasi sumuran pada kedalaman $4 \mathrm{~m}$. Data yang digunakan untuk analisis adalah data sekunder yang berasal dari PT. Citra Komunikasi Perkasa. Hasil analisis kapasitas dukung fondasi sumuran untuk beban yang bekerja di sepanjang abutmen yaitu $\mathrm{P}=8536.52 \mathrm{kN}$ dengan diameter sumuran $3 \mathrm{~m}$ dan kedalaman $4 \mathrm{~m}$ didapatkan $\mathrm{Qg}=12051.32 \mathrm{kN}>\mathrm{P}=8536.52 \mathrm{kN}$. Perhitungan stabilitas fondasi terhadap beban horizontal pada abutmen didapatkan $\Sigma \mathrm{H}=7662.117 \mathrm{kN}>$ Beban horizontal yang bekerja di sepanjang abutmen yaitu $\Sigma T y=964.180 \mathrm{kN}$. Untuk perhitungan penurunan fondasi sumuran tunggal pada abutmen sebesar $\mathrm{S}=130.008 \mathrm{~mm}$, dimana penurunan yang terjadi memenuhi syarat $<$ Sijin yaitu $250 \mathrm{~mm}$.
\end{abstract}

Kata kunci: Pondasi sumuran, SPT, daya dukung, penurunan.

\section{Pendahuluan}

Fondasi sumuran merupakan peralihan antara fondasi dalam dan fondasi dangkal. Penyelidikan perilaku fondasi dangkal dalam mendukung sistem jembatan dibawah eksitasi seismik dengan perlakuan tanah/batuan yang homogen dan mengasumsikan perilaku elastis linier dari kolom dermaga dan elemen struktur [1-6]. Fondasi sumuran umumnya digunakan dalam perancangan jembatan [7]. Menurut Aswathy dan Jacob (2015) menjelaskan bahwa fondasi sumuran banyak digunakan sebagai penyangga dan jangkar struktur utama jembatan terutama yang mempunyai bentang yang panjang dan struktur yang sangat berat [8]. Jembatan merupakan suatu konstruksi yang gunanya untuk meneruskan jalan melalui suatu rintangan yang berada lebih rendah, dimana rintangannya yaitu jalur air atau jalan lalu lintas biasa [9].

Jembatan Pombewe merupakan jembatan yang dibangun oleh PT. Citra Komunikasi Perkasa pada Tahun 2019. Jembatan Pombeve sangat berperan vital dalam menghubungkan kedua desa antara Desa Pombeve dan Desa Sidera dalam segi transportasi umum maupun untuk kepentingan perekonomian. Fondasi yang digunakan pada proyek pembangunan jembatan Pombeve ialah fondasi sumuran pada kedua abutment yaitu abutmen arah
Pombewe dan abutmen arah sidera dengan bentang jembatan mencapai $50 \mathrm{~m}$ dan lebar $9 \mathrm{~m}$ dapat dilihat pada Gambar 1. Pada jembatan Pombewe fondasi sumuran mempunyai kedalaman fondasi $7 \mathrm{~m}$ dan diameter $3 \mathrm{~m}$, berdasarkan nilai SPT pada kedua abutmen diperoleh kedalaman tanah keras pada abutmen arah Pombeve adalah $7 \mathrm{~m}$ dan abutmen arah Sidera pada kedalaman $4 \mathrm{~m}$ tetapi dalam perencanaan menetapkan pada kedua abutment kedalaman fondasi adalah $7 \mathrm{~m}$ dengan diameter $3 \mathrm{~m}$ berdasarkan perhitungan kapasitas dukung menggunakan data tanah sehingga apabila dilihat dari segi waktu pelaksanaan dan biaya kurang efektif. Hardiyatmo (2017) menyatakan bahwa menentukan kedalaman fondasi dengan jalan memilih kedalaman yang minimum yang memenuhi syarat keamanan terhadap kapasitas dukung tanah [10]. Berdasarkan hal tersebut, maka penulis ingin merencanakan kembali fondasi pada jembatan Pombewe khususnya pada abutmen arah Sidera berdasarkan hasil uji Penetrasi Standar (SPT) untuk mendapatkan perencanaan yang lebih efektif dalam segi waktu dan biaya. Fondasi sumuran merupakan jenis peralihan antara fondasi dangkal dan fondasi dalam. Biaya pembuatan fondasi yang relatif murah, pondasi sumuran telah banyak dipakai untuk mendukung bangunan- 
bangunan gedung, jembatan, pilar jembatan layang dan lain sebagainya [10].

Tabel 1. Persyaratan penurunan fondasi [11].

\begin{tabular}{lc}
\hline \multicolumn{1}{c}{ Jenis Bangunan } & Penurunan Maksimum (cm) \\
\hline Bangunan Umum & 2.54 \\
\hline Bangunan Pabrik & 3.81 \\
\hline Gudang & 5.08 \\
\hline Fondasi Mesin & 0.05 \\
\hline
\end{tabular}

Merancang suatu fondasi yang perlu diperhatikan adalah penurunan dari fondasi. Menurut Teng (1992) tidak boleh terjadi penurunan pada pondasi setempat ataupun penurunan merata melebihi dari batas - batas penurunan tertentu [11], seperti yang ditunjukkan pada Tabel 1.

Tujuan dari penelitian ini adalah untuk menganalisis kembali kapasitas dukung fondasi sumuran berdasarkan nilai Uji Penetrasi Standar (SPT).

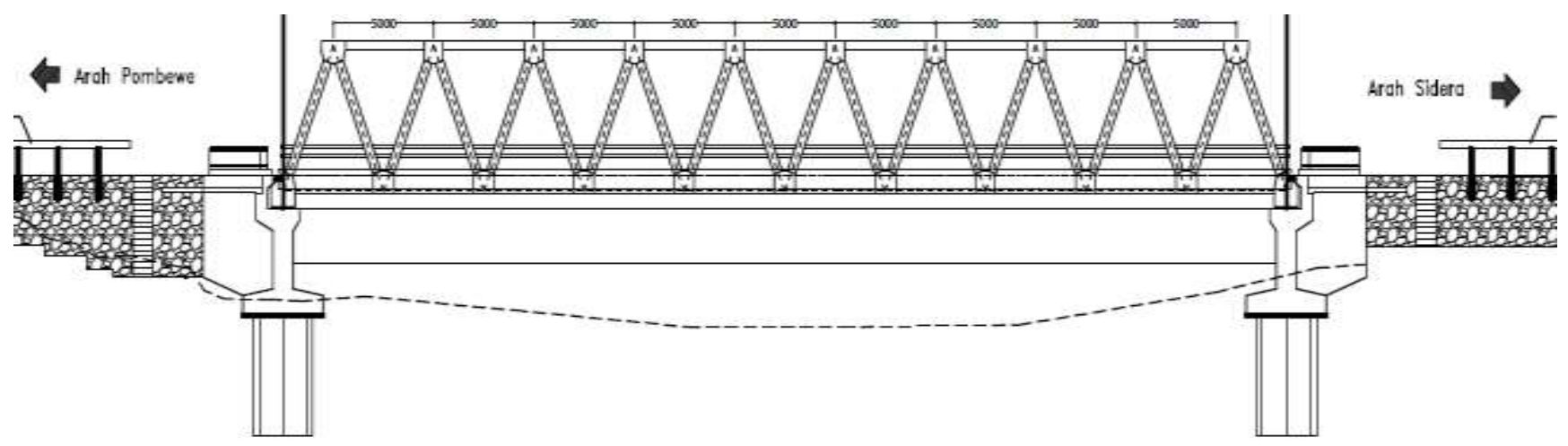

Gambar 1. Potongan memanjang Jembatan Pombeve

\section{Metode Penelitian}

\subsection{Pengumpulan Data}

Data yang dibutuhkan dalam penelitian ini adalah data sekunder. Data sekunder diperoleh dari instansi-instansi terkait adalah sebagai berikut:

1) Data Tanah

Merupakan data sekunder hasil pengujian Boring dan SPT yang dilakukan oleh PT. Citra Komunikasi Perkasa
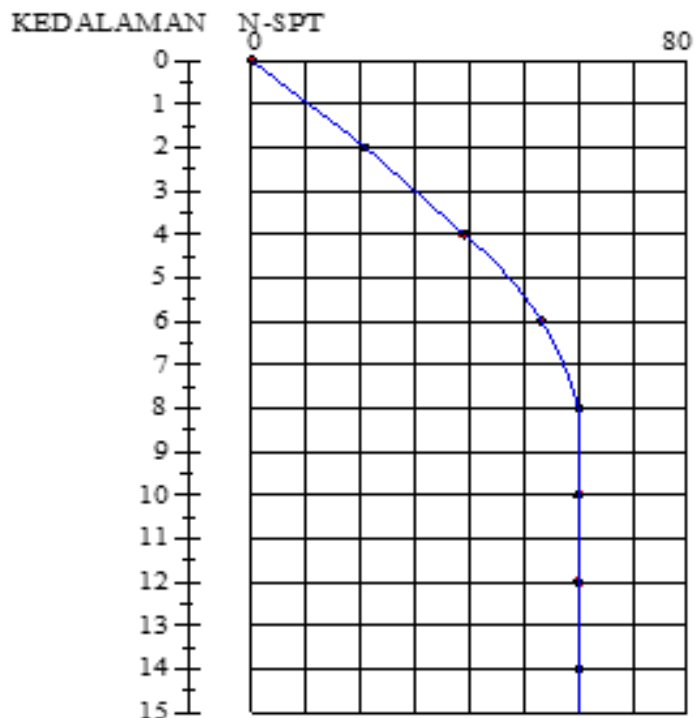

pada proyek Jembatan Pombeve yang dilakukan pada tahun 2019 terhadap 2 (dua) titik pengujian masingmasing pada pondasi untuk abutment dengan nomor pengujian BH-1 (arah Pombewe) dan BH-2 (arah Sidera) Hasil pengujian SPT dapat dilihat pada Gambar 2. Nilai N-SPT yang digunakan pada penelitian ini adalah pada kedalaman $4 \mathrm{~m}, 5 \mathrm{~m}, 6 \mathrm{~m}$ dan $7 \mathrm{~m}$ untuk BH-2 abutmen arah sidera

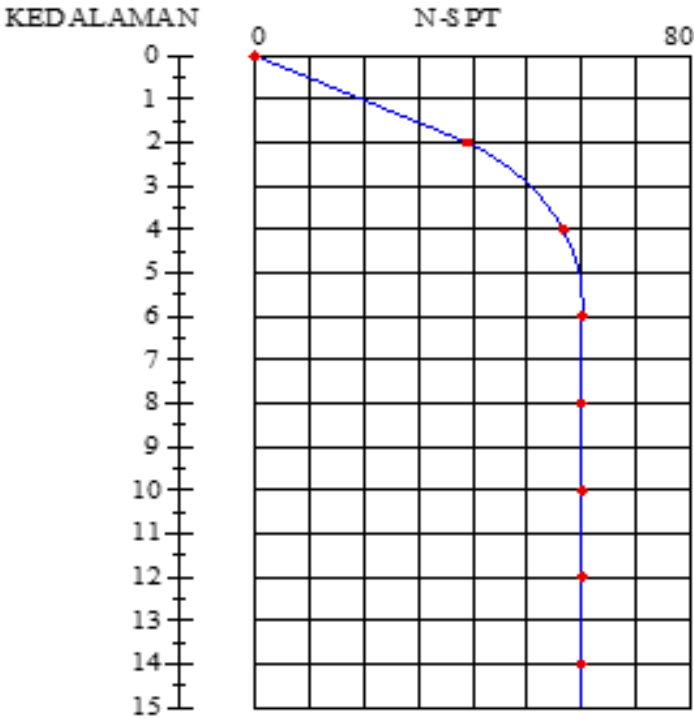

Gambar 2. Data SPT BH-01 dan SPT BH-02

2) Data Bangunan Atas

Data bangunan atas jembatan Pombeve diperoleh dari dokumen hasil perencanaan teknis jembatan. Data bangunan atas yang digunakan adalah data yang berkaitan dengan pembangunan jembatan Pombeve diperoleh dari PT. Citra Komunikasi Perkasa. Kemudian dilakukan analisis kembali beban yang bekerja 
REKOnSTRUKSI TADULAKO: Civil Engineering Journal on Research and Development, Vol. 1(2), September 2020

berdasarkan dimensi bangunan atas yang sudah ada menggunakan gambar perencaan jembatan Pombeve

3) Spesifikasi Jembatan

\section{Umum}

Informasi umum mengenai jembatan adalah sebagai berikut:
a) Nama Jembatan
: Jembatan Pombeve - Sidera
b) Jenis jembatan
: Lalu lintas atas
c) Tipe struktur atas
: Jembatan Rangka Baja
d) Status jalan
Sekunder
e) Bentang jembatan : $50 \mathrm{~m}$
f) Lebar jembatan
: $9 \mathrm{~m}$
g) Lebar jalur
: $2 \times 3.5 \mathrm{~m}$
h) Lebar trotoar
: $1 \mathrm{~m}$
i) Bangunan bawah
: Abutment tembok penahan
j) Tipe fondasi
: Pondasi sumuran

\section{Acuan Normatif}

Adapun standar/code yang digunakan dalam perencanaan adalah:

a) SNI 1725-2016 tentang Pembebanan Untuk Jembatan

b) SNI2833-2016 tentang Perencanaan Jembatan Terhadap Beban Gempa

c) SNI2847-2013 tentang Persyaratan Beton Struktural Untuk Bangunan Gedung

Tabel 1. Rekapitulasi gaya pada fondasi

\begin{tabular}{|c|c|c|c|c|c|c|}
\hline \multicolumn{7}{|c|}{ 1. Beban Mati } \\
\hline & Beban mati & MS & 3004.831 & & 0 & 0 \\
\hline & Beban mati tambahan & MA & 887.338 & & 0 & 0 \\
\hline \multirow[t]{4}{*}{2.} & Tekanan Tanah & & & & & \\
\hline & Tekanan tanah(1) & TA & & 0.77 & 3.25 & 2.503 \\
\hline & Tekanan tanah(2) & TA & & 369.688 & 2.167 & 800.990 \\
\hline & Tekanan Tanah Total & TA & & 370.458 & 2.169 & 803.492 \\
\hline \multicolumn{7}{|c|}{ 3. Beban LaluLintas } \\
\hline & Beban terbagirata & BTR & 1260 & & & \\
\hline & Beban garis & BGT & 171.5 & & & \\
\hline & Beban truk & TT & 250 & & & \\
\hline & Beban PejalanKaki & $\mathrm{TP}$ & 250 & & & \\
\hline & Gaya Rem & TB & & 151.0 & 5.0 & 755 \\
\hline & Gaya Gempa & EQ & & 425.6 & 5.0 & 2128.038 \\
\hline 7 & Beban Angin Pada Struktur & EWs & & 337.82 & 5.0 & 1689.098 \\
\hline
\end{tabular}

Tabel 2. Rekapitulasi kombinasi pembebanan

\begin{tabular}{|c|c|c|c|c|c|c|c|c|c|c|c|c|c|c|}
\hline \multirow{2}{*}{$\begin{array}{c}\text { Keadaan } \\
\text { Batas }\end{array}$} & \multicolumn{9}{|c|}{ BEBAN (kN) } & \multicolumn{5}{|c|}{ TOTAL BEBAN } \\
\hline & MS & MA & TA & $\mathbf{T T}$ & TD & TB & $\mathbf{T P}$ & EWs & $\mathbf{E Q}$ & $\begin{array}{c}\mathrm{V} \\
(\mathrm{kN})\end{array}$ & $\begin{array}{c}\mathbf{H x} \\
(\mathbf{k N})\end{array}$ & $\begin{array}{c}\text { Hy } \\
(\mathbf{k N})\end{array}$ & $\begin{array}{c}\begin{array}{c}\text { Mx } \\
(\mathbf{k N m})\end{array} \\
\end{array}$ & $\begin{array}{c}\begin{array}{c}\text { My } \\
(\mathrm{kNm})\end{array} \\
\end{array}$ \\
\hline Kuat I & 3906 & 1154 & 463 & 450 & 2577 & 272 & 450 & 0 & 0 & 8537 & 735 & 0 & 2363 & 0 \\
\hline Kuat II & 3906 & 1154 & 463 & 350 & 2004 & 211 & 350 & 0 & 0 & 7764 & 674 & 0 & 2061 & 0 \\
\hline Kuat III & 3906 & 1154 & 463 & 0 & 0 & 0 & 0 & 473 & 0 & 5060 & 463 & 473 & 1004 & 3074 \\
\hline Kuat IV & 3906 & 1154 & 463 & 0 & 0 & 0 & 0 & 0 & 0 & 5060 & 463 & 0 & 1004 & 0 \\
\hline Kuat V & 3906 & 1154 & 463 & 0 & 0 & 0 & 0 & 135 & 0 & 5060 & 463 & 135 & 1004 & 878 \\
\hline Ekstrem I & 3906 & 1154 & 463 & 125 & 716 & 76 & 125 & 0 & 426 & 603 & 964 & 0 & 3510 & 0 \\
\hline Ekstrem II & 3906 & 1154 & 463 & 125 & 716 & 76 & 125 & 0 & 0 & 603 & 539 & 0 & 1382 & 0 \\
\hline $\begin{array}{l}\text { Daya } \\
\text { Layan I }\end{array}$ & 3005 & 887 & 370 & 250 & 1432 & 151 & 250 & 101 & 0 & 5824 & 521 & 101 & 1558 & 659 \\
\hline $\begin{array}{l}\text { Daya } \\
\text { Layan II } \\
\end{array}$ & 3005 & 887 & 370 & 325 & 1432 & 151 & 250 & 0 & 0 & 5899 & 521 & 0 & 1558 & 0 \\
\hline $\begin{array}{l}\text { Daya } \\
\text { Layan III }\end{array}$ & 3005 & 887 & 370 & 200 & 1145 & 121 & 200 & 0 & 0 & 5437 & 491 & 0 & 1407 & 0 \\
\hline $\begin{array}{l}\text { Daya } \\
\text { Layan IV } \\
\end{array}$ & 3005 & 887 & 370 & 0 & 0 & 0 & 0 & 236 & 0 & 3892 & 370 & 236 & 803 & 1537 \\
\hline \multicolumn{10}{|c|}{ BEBAN MAKSIMAL } & 8537 & 964 & 473 & 3510 & 3074 \\
\hline
\end{tabular}

\subsection{Perencanaan Pondasi Sumuran}

1) Kapasitas Daya Dukung Fondasi Sumuran Perhitungan daya dukung ultimit (Qult) fondasi sumuran menggunakan persamaan dibawah ini:

$Q u l t=Q p+Q s$
Untuk persamaan daya dukung ijin (Qall) menggunakan persamaan 2 dibawah ini:

Qall $=\frac{Q u}{F s}$

dimana:

$\mathrm{Q}_{\mathrm{ult}}=$ kapasitas daya dukung ultimit total $(\mathrm{kN})$ 
$\mathrm{Q}_{\mathrm{p}}=$ kapasitas daya dukung ultimit tahanan ujung $(\mathrm{kN})$

Qs = kapasitas daya dukung ultimit geser selimut $(\mathrm{kN})$

$\mathrm{Q}_{\text {all }}=$ kapasitas daya dukung ijin $(\mathrm{kN})$

$\mathrm{FS}=$ Faktor keamanan

Untuk menentukan jumlah tiang persamaan yang digunakan adalah sebagai berikut:

$\mathrm{n}=\frac{P u}{\text { Qall }}$

dimana:

$\mathrm{Pu}=$ beban yang bekerja pada abutment/pier $(\mathrm{kN})$

$\mathrm{n}=$ jumlah tiang (buah)

2) Kapasitas Dukung Fondasi Sumuran Menggunakan Data N-SPT

Kapasitas ultimit tiang dapat dihitung secara empiris dari nilai $N$ hasil uji SPT. Meyerho (1976) mengusulkan persamaan untuk menghitung tahanan ujung tiang sebagai berikut [12]:

$\mathrm{Q}_{\mathrm{p}}=\mathrm{A}_{\mathrm{p}} \mathrm{x}(38 \mathrm{x} \bar{N}) \mathrm{x}\left(\mathrm{L}_{\mathrm{b}} / \mathrm{d}\right) \leq 380 \mathrm{x} \bar{N}_{\mathrm{x}}\left(\mathrm{A}_{\mathrm{p}}\right)$

Untuk tahanan gesek satuan pada tanah tidak kohesif (pasir):

$\mathrm{Qs}=\frac{1}{50} x$ or $x 60$

dimana:

$\mathrm{Q}_{\mathrm{P}}=$ tahanan ujung tiang $(\mathrm{kN})$

$\mathrm{Q}_{\mathrm{s}}=$ tahanan gesek tiang $(\mathrm{kN})$

$\bar{N}=$ nilai rata-rata $\mathrm{N}-\mathrm{SPT}$ pada dasar tiang $((\mathrm{N} 1+\mathrm{N} 2) / 2)$.

$\mathrm{N} 1=$ nilai rata-rata N-SPT pada kedalaman $8 \mathrm{~d}$ di atas dasar tiang

$\mathrm{N} 2=$ nilai rata-rata $\mathrm{N}-\mathrm{SPT}$ pada kedalaman $4 \mathrm{~d}$ di bawah dasar tiang

$\mathrm{N}_{60}=\mathrm{N}-\mathrm{SPT}$ yang dikoreksi terhadap pengaruh prosedur lapangan

$\sigma_{\mathrm{r}}=$ tegangan refrensi $=100 \mathrm{kN} / \mathrm{m}^{2}$

$\mathrm{A}_{\mathrm{p}}=$ luas tiang $\left(\mathrm{m}^{2}\right)$

$\mathrm{L}_{\mathrm{b}} / \mathrm{d}=$ rasio kedalaman

3) Penurunan Fondasi Sumuran

Kegagalan kuat dukung (bearing capacity failure) tanah, pada setiap proses penggalian selalu dihubungkan dengan perubahan keadaan tegangan di dalam tanah. Perubahan tegangan pasti akan disertai dengan perubahan bentuk, pada umumnya hal ini yang menyebabkan penurunan pada fondasi [10].

\section{Penurunan Tiang Tunggal}

Penurunan jangka panjang untuk pondasi tiang tunggal tidak perlu ditinjau karena penurunan tiang akibat konsolidasi dari tanah relatif kecil. Hal ini disebabkan karena fondasi tiang direncanakan terhadap kuat dukung ujung dan kuat dukung friksinya atau penjumlahan dari keduanya [10].

Untuk perencanaan, penurunan elastis pondasi tiang tunggal akibat beban vertikal yang bekerja dapat dihitung sebagai berikut (Metode semi empiris):
$\mathrm{S}=\mathrm{S}_{1}+\mathrm{S}_{2}+\mathrm{S}_{3}$

dimana:

$\mathrm{S}=$ penurunan elastis total fondasi tiang tunggal $(\mathrm{mm})$

$\mathrm{S}_{1}=$ penurunan akibat deformasi aksial tiang tunggal $(\mathrm{mm})$

$\mathrm{S}_{2}=$ penurunan dari ujung tiang $(\mathrm{mm})$

$\mathrm{S}_{3}=$ penurunan akibat beban yang dialihkan sepanjang tiang $(\mathrm{mm})$

$\mathrm{S}_{1}, \mathrm{~S}_{2}$ dan $\mathrm{S}_{3}$ di hitung dengan:

$\mathrm{S}_{1}=\frac{\left(\mathrm{Q}_{w p}+\xi \mathrm{Q}_{w s}\right) \mathrm{L}}{\operatorname{Ap} \times \mathrm{Ep}}$

dimana:

$\mathrm{Q}_{\mathrm{wp}}=$ beban yang dipikul ujung tiang akibat beban bekerja $(\mathrm{kN})$

$\mathrm{Q}_{\mathrm{ws}}=$ beban yang dipikul selimut tiang akibat beban kerja $(\mathrm{kN})$

$A_{p} \quad=$ luas penampang tiang $\left(\mathrm{mm}^{2}\right)$

$\mathrm{L} \quad=$ panjang tiang tertanam $(\mathrm{mm})$

$\mathrm{E}_{\mathrm{p}}=$ modulus elastis material tiang $\left(\mathrm{kN} / \mathrm{mm}^{2}\right)$

$\xi \quad=0,50$ untuk tanah lempung 0,67 untuk tanah pasir

$\mathrm{S}_{2}=\frac{\mathrm{Qwp} \times \mathrm{Cp}}{\mathrm{D} \times \mathrm{qp}}$

Keterangan:

$\mathrm{Cp}=$ koefisien empiris

$q_{p}=$ beban persatuan luas pada ujung tiang, $Q_{w p} / A_{p}(\mathrm{kN}$ $/ \mathrm{m}^{2}$ )

$\mathrm{D}=$ diameter lebar tiang $(\mathrm{mm})$

S3 $=\frac{\text { Qwp } \times \text { Cs }}{\mathrm{L} \times \mathrm{qp}}$

dimana $\mathrm{Cs}=$ konstanta empiris $=(0,93+0,16 \sqrt{\mathrm{L}} / \mathrm{D}) \mathrm{Cp}$

4) Kontrol Stabilitas Fondasi Sumuran

Kontrol stabilitas fondasi sumuran terhadap beban vertikal (Pv) dan momen (M) yang bekerja (titik CL). Gaya vertikal dipikul hanya oleh tiangnya sendiri. Ini berarti bahwa pier tidak dapat diperhitungkan untuk mendukung beban langsung yang didukung oleh tanah dibawah pier akan selalu tidak asli lagi dan sudah banyak terganggu sehingga akan terjadi banyak rongga pada lapisan tersebut. Akibatnya tanah akan menjadi lembek dan mudah turun (settle) [13]. Untuk menghitung gaya vertikal tiang digunakan rumus:

$\mathrm{Pv}=\frac{\mathrm{P} \cdot \mathrm{By}}{\mathrm{n}} \pm \frac{\mathrm{M} \cdot \mathrm{By}}{\mathrm{m}\left(\mathrm{Sn}^{\prime}\right)}+\mathrm{Wp}$

Syarat : $0<\mathrm{Pv} \min <\mathrm{Pv}$ maks $<\mathrm{Qu}$

Keterangan:

$\mathrm{Pv}=$ beban vertikal $(\mathrm{Kg})$

$\mathrm{P}=$ beban yang bekerja per meter lebar abutment pier

By $=$ lebar abutment pier arah y (m)

$\mathrm{n}=$ jumlah tiang

n' = jumlah tiang satu baris dikurangi satu (n-1)

$\mathrm{m}=$ jumlah baris

$\mathrm{M}=$ momen yang bekerja pada pondasi (kN.m)

$\mathrm{S}=$ jarak antar tiang terluar $(\mathrm{m})$

$\mathrm{Wp}=$ berat tiang $(\mathrm{kN})$ 
2.3. Hasil Analisis Kapasitas Dukung Fondasi Sumuran Berdasarkan Data Tanah Untuk Kedalaman 7 M di Lapangan

Berdasarkan hasil analisis kapasitas dukung menggunakan data tanah yang telah dilakukan oleh PT. Citra Komunikasi Perkasa, 2019 diperoleh nilai sebagai berikut;

1) Kestabilan terhadap geser

$\mathrm{SF}_{\text {geser }}=3.687>1.5$ struktur aman

2) Kestabilan terhadap guling

SFguling $=2.0 \geq 2$ struktur aman

3) Kestabilan terhadap daya dukung tanah

$\mathrm{SFf}=4.5622>3$ struktur aman

\section{Hasil dan Pembahasan}

\subsection{Menghitung Kapasitas Dukung Fondasi Sumuran} Menggunakan Data N-SPT

Analisis Fondasi sumuran pada abutment arah sidera berdasarkan nilai N-SPT diambil kedalaman $4 \mathrm{~m}, 5 \mathrm{~m}, 6 \mathrm{~m}$ dan $7 \mathrm{~m}$. Diameter fondasi sumuran $3 \mathrm{~m}$ dengan beban 813.002. Data yang digunakan sebagai berikut;

a) Kedalaman (L) $=4 \mathrm{~m}$.

b) $\mathrm{By}=10.5 \mathrm{M}$ (lebar keseluruhan abutment)

c) $\mathrm{Pu}=\mathrm{V}_{\text {MAKS }} / \mathrm{By}=8536.52 / 10.5=813.002 \mathrm{kN} / \mathrm{m}$

d) $\mathrm{Hu}=\mathrm{Hx}_{\mathrm{MAKS}} / \mathrm{By}=964.18 / 10.5=91.827 \mathrm{kN} / \mathrm{m}$

e) $\mathrm{Mu}=\mathrm{Mx}_{\mathrm{MAKS}} / \mathrm{By}=3509.90 / 10.5=364.37 \mathrm{kNm}$

f) $\operatorname{Diameter}(\mathrm{d})=3 \mathrm{~m}$.

g) Luas tiang $(\mathrm{Ap})=1 / 4 \times \pi \times\left(\mathrm{d}^{2}\right)=1 / 4 \times \pi \times\left(3^{2}\right)=7.065 \mathrm{~m}^{2}$

Menghitung tahanan ujung pondasi sumuran (Qp):

$\mathrm{Qp}=\operatorname{Ap}(38 \times \bar{N}) \times\left(\mathrm{L}_{\mathrm{b}} / \mathrm{d}\right) \leq 380 \times \bar{N} \times($ Ap $)$

dengan:

$\mathrm{L} / \mathrm{d}=4.0 \mathrm{~m} / 3 \mathrm{~m}=1.33$

$\bar{N}=$ nilai rata-rata N-SPT pada dasar tiang $(\mathrm{N} 1+\mathrm{N} 2) / 2)$

$\mathrm{N} 1=$ nilai rata-rata $\mathrm{N}-\mathrm{SPT}$ pada kedalaman $8 \mathrm{~d}$ di atas dasar tiang $8 \times 3=24 \mathrm{~m}$. karena kedalaman hanya 4 m. Maka nilai N1 $=(19+39+50+56) / 4=41$

$\mathrm{N} 2=$ nilai rata-rata $\mathrm{N}-\mathrm{SPT}$ pada kedalaman $4 \mathrm{~d}$ di bawah dasar tiang 4 × $3=12 \mathrm{~m}$. Maka nilai N2 $=60$, karna semua nilai yang kebawah dianggap sudah tanah keras maka dianggap semua 60

$$
\begin{aligned}
\bar{N} & =(41+60) / 2=50.5 \\
\mathrm{Qp} & =7.065 \times(38 \times 50.5) \times(1.33) \leq 380 \times 50.5 \times(7.065) \\
& =18076.98 \mathrm{kN}<135577.4 \mathrm{kN} \\
& =18076.98 \mathrm{kN}
\end{aligned}
$$

Menghitung tahanan gesek tiang (Qs):

$$
\begin{aligned}
\text { Qs } & =\frac{1}{50} \times \sigma_{\mathrm{r}} \times \mathrm{N}_{60} \\
\mathrm{~N}_{60} & =\frac{1}{0.6} \times \mathrm{Ef} \times \mathrm{Cb} \times \mathrm{Cs} \times \mathrm{Cr} \times \mathrm{N} \\
\mathrm{Ef} & =\text { Hammer Eficiency }=0.55 \\
\mathrm{Cb} & =\text { koreksi diameter bor }=1 \\
\mathrm{Cs} & =\text { Koreksi Sampler }=1 \\
\mathrm{Cs} & =\text { Koreksi Panjang Tali }=0.75 \\
\mathrm{~N} & =\mathrm{N}-\mathrm{Spt} \text { pada kedalaman yang ditinjau }=56 \\
\mathrm{~N}_{60} & =\frac{1}{0.6} \times 0.55 \times 1 \times 1 \times 0.75 \times 56=38.5 \\
\sigma_{\mathrm{r}} & =\text { tegangan referensi }=100 \mathrm{kN} / \mathrm{m}^{2}
\end{aligned}
$$

$$
\text { Qs }=\frac{1}{50} \times 100 \times 38.50=77 \mathrm{kN}
$$

\subsection{Menghitung Kapasitas Ultimit Tiang (Qu)}

Nilai Qp dan Qs kapasitas dukung fondasi sumuran menggunakan data N-SPT.

dengan:

$\mathrm{Qp}=18076.96 \mathrm{kN}$

$\mathrm{Qs}=77 \mathrm{kN}$

$\mathrm{Qu}=\mathrm{Qp}+\mathrm{Qs}=18076 \mathrm{kN}+77 \mathrm{kN}=18153 \mathrm{kN}$

3.3. Menghitung Kapasitas dukung izin tiang (Qall)

Qall $=\mathrm{Qu} / \mathrm{FS}=18153 \mathrm{kN} / 3=6025.66 \mathrm{kN}$

Beban yang bekerja disepanjang abutment:

$\mathrm{P}=\mathrm{Pu} \times \mathrm{By}=813.002 \mathrm{kN} / \mathrm{m} \times 10.5 \mathrm{~m}=8536.52 \mathrm{kN}$

Menentukan jumlah tiang yang diperlukan:

$\mathrm{N}=\frac{P}{\text { Qall }}=\frac{8536.52 \mathrm{kN}}{6025.66 \mathrm{kN}}=1.417 \approx 2$ buah

Daya dukung untuk pondasi sumuran kelompok:

Qg $=\mathrm{n} \times$ Qall $=2 \times 6025.66 \mathrm{kN}$

$$
=12051.32 \mathrm{kN}>\mathrm{P}=8536.520 \mathrm{kN} \quad \ldots \text { (aman) }
$$

3.4. Kontrol Stabilitas Fondasi Terhadap Beban Vertikal (Pv) Dan Momen (M) yang Bekerja

$\mathrm{Pv}=\frac{P x B y}{n} \pm \frac{M x B y}{m\left(S n^{\prime}\right)}+\mathrm{Wp}$

Dengan berat sendiri fondasi:

$$
\begin{aligned}
\mathrm{Wp}= & \left(\pi \times \mathrm{x} \mathrm{n}^{2}\right) \times \mathrm{h} \times \Upsilon_{\text {beton }}=\left(\pi .1^{2}\right) \times 4 \times 24=301.44 \mathrm{kN} \\
\mathrm{Pv}= & \frac{813.002 \times 10.5}{2} \pm \frac{334.27619 \times 10.5}{1(3 \times 1)}+301.44 \\
= & 4268.26 \mathrm{kN} \pm 1169.967 \mathrm{kN}+301.44 \mathrm{kN} \\
\mathrm{Pv} \max & =4268.26 \mathrm{kN}+1169.967 \mathrm{kN}+301.44 \mathrm{kN} \\
& =5739.667 \mathrm{kN} \\
\mathrm{Pv} \min & =4268.26 \mathrm{kN}-1169.967 \mathrm{kN}+301.44 \mathrm{kN} \\
& =3399.733 \mathrm{kN} \\
\text { Syarat }: & 0<\mathrm{Pv} \min <\mathrm{Pv} \max <\mathrm{Qu} \\
& : 0<3399.733 \mathrm{kN}<5739.667 \mathrm{kN}<18076.980 \\
& \mathrm{kN} \ldots \ldots .(\text { aman })
\end{aligned}
$$

3.5. Kontrol Stabilitas Fondasi Terhadap Beban Horizontal $(H)$

$H=\frac{K \times D}{\beta} \delta_{\mathrm{a}}$

dengan:

$\beta=\sqrt[4]{\frac{K \times D}{4 E x I}}$

$\mathrm{K}=0.75 \mathrm{~kg} / \mathrm{cm}^{3}$ (untuk jenis tanah pasir kasar) [14-17].

$\delta_{\mathrm{a}}=1 \mathrm{~cm}$ (besarnya pergeseran normal)

$\mathrm{E}=235000 \mathrm{~kg} / \mathrm{cm}^{2}$

I $=1 / 4 \times \pi \times r^{4}=1 / 4 \times \pi \times 150^{4}=2011869141 \mathrm{~cm}^{4}$

$\mathrm{D}=300 \mathrm{~cm}$

$\beta=\sqrt[4]{\frac{0,75 \times 200}{4 \times 235000 \times 2011869141}}=0.00059 \mathrm{~cm}$

$\mathrm{H}=\frac{0,75 \times 300}{0.00059} \times 1=383105.851 \mathrm{~kg}=3831.059 \mathrm{kN}$

Jumlah fondasi di abutment $=2$ buah

$\Sigma \mathrm{H}=\mathrm{n} \times \mathrm{H}=2 \times 3821.059=7662.117 \mathrm{kN}$

Beban Hu yang bekerja disepanjang abutment:

$\Sigma$ ty $=\mathrm{Hu} \times \mathrm{By}=964.180 \times 10.5$

$$
=964.180 \mathrm{kN}<\Sigma \mathrm{H}=7662.117 \mathrm{kN} \ldots \text { (aman) }
$$




\subsection{Penurunan Fondasi Sumuran Pada Abutment}

1) Penurunan Fondasi Sumuran Tunggal Penurunan fondasi tiang tunggal dihitung dengan menggunakan metode semi empiris.

Diketahui:

$$
\begin{aligned}
& \mathrm{Qp}=18077 \mathrm{kN}=18076980 \mathrm{~N} \\
& \text { Qs }=77 \mathrm{kN}=77000 \mathrm{~N} \\
& \mathrm{Qg}=12051.32 \mathrm{kN}=12051320 \mathrm{~N} \\
& \mathrm{D}=3.0 \mathrm{~m}=3000 \mathrm{~mm} \\
& \text { Ap }=\pi \times \mathrm{r}^{2}=3,14 \times 1500^{2}=7065000 \mathrm{~mm}^{2} \\
& \xi \quad=0,67 \text { (untuk jenis tanah pasir) } \\
& \mathrm{F}^{\prime} \mathrm{c}=25 \mathrm{MPa} \\
& \mathrm{Ep}=4700 \sqrt{F c}=4700 \sqrt{25}=23500 \mathrm{MPa} \\
& \mathrm{L} \quad=4.0 \mathrm{~m}=4000 \mathrm{~mm}
\end{aligned}
$$

Untuk beban yang diperhitungkan, ujung tiang sumuran (Qwp) dan kulit tiang (Qws).

Beban yang didukung ujung tiang sumuran (Qwp):

$$
\begin{aligned}
\mathrm{Qwp} & =\left(\frac{Q p}{Q p+Q s}\right) \times \mathrm{Qg}=\left(\frac{187076980}{187076980+77000}\right) \times 12051320 \\
& =120000204.4 \mathrm{~N}
\end{aligned}
$$

Beban yang didukung kulit tiang sumuran (Qws):

$$
\begin{aligned}
\text { Qws } & =\left(\frac{Q s}{Q s+Q p}\right) \times Q g=\left(\frac{77000}{77000+187076980}\right) \times 12051320 \\
& =51115.6033 \mathrm{~N}
\end{aligned}
$$

Penurunan akibat deformasi aksial tiang semuran $\left(\mathrm{S}_{1}\right)$ :

$$
\begin{aligned}
\mathrm{S}_{1} & =\frac{\mathrm{Qwp}+\xi \mathrm{qws}) \mathrm{L}}{\mathrm{Ap} \times \mathrm{Ep}}=\frac{(12000204.4+0.67 \times 51115.6033) 4000}{7065000 \times 23500} \\
& =0.290 \mathrm{~mm}
\end{aligned}
$$

Penurunan dari ujung tiang $\left(\mathrm{S}_{2}\right)$ :

$\mathrm{Qp}=\frac{\mathrm{Qwp}}{\mathrm{Ap}}=\frac{12000204.4}{7065000}=1.699 \mathrm{~N} / \mathrm{mm}^{2}$

$\mathrm{Cp}=0.03$

$\mathrm{S}_{2}=\frac{\mathrm{Qwp} \times \mathrm{Cp}}{\mathrm{D} \times \mathrm{qp}}=\frac{12000204.4 \times 0.03}{3000 \times 1.699}=70.650 \mathrm{~mm}$

Penurunan akibat beban yang dialihkan sepanjang tiang $\left(\mathrm{S}_{3}\right)$ :

$$
\begin{aligned}
\mathrm{S}_{3} & =\frac{\text { Qwp } \times \mathrm{Cs}}{\mathrm{L} \times \mathrm{qp}} \\
\mathrm{Cs} & =(0.93+0.16 \sqrt{L} / D) \mathrm{Cp} \\
& =(0.93+0.16 \sqrt{1.33}) \times 0.03=0.033 \\
\mathrm{~S}_{3} & =\frac{12000204.4 \times 0.033}{4000 \times 1.699}=59.068 \mathrm{~mm}
\end{aligned}
$$

Maka, penurunan total tiang $(\mathrm{S})$ :

$$
\mathrm{S}=\mathrm{S} 1+\mathrm{S} 2+\mathrm{S} 3=0.290+70.650+59.068
$$$$
=130.008 \mathrm{~mm}
$$

\subsection{Pembahasan Hasil Analisis}

Hasil dari analisis kapasitas dukung fondasi sumuran pada abutment Sidera berdasarkan nilai N-SPT dengan kedalaman $4 \mathrm{~m}, 5 \mathrm{~m}, 6 \mathrm{~m}$, dan $7 \mathrm{~m}$ dapat dilihat pada Tabel 3 dan Gambar 3.

Tabel 3. Hasil analisis daya dukung fondasi sumuran pada abutment Sidera

\begin{tabular}{ccccccc}
\hline $\begin{array}{c}\text { Kedalaman } \\
\text { Fondasi } \\
(\mathbf{m})\end{array}$ & $\begin{array}{c}\text { Diameter } \\
\text { Fondasi }\end{array}$ & \multicolumn{5}{c}{ Daya Dukung Fondasi Sumuran } \\
\cline { 3 - 7 }$(\mathbf{m})$ & 3 & Qp $(\mathbf{K N})$ & $\begin{array}{c}\text { Qs } \\
(\mathbf{K N})\end{array}$ & Qult $(\mathbf{K N})$ & FS & $\begin{array}{c}\text { Qall } \\
(\mathbf{K N})\end{array}$ \\
\hline 4 & 3 & 23433.89 & 77 & 23433.89 & 3 & 7811.29 \\
\hline 5 & 3 & 28726.29 & 77 & 28803.29 & 3 & 9601.1 \\
\hline 6 & 3 & 34095.69 & 77 & 34172.69 & 3 & 11390.9 \\
\hline 7 & & & & & &
\end{tabular}

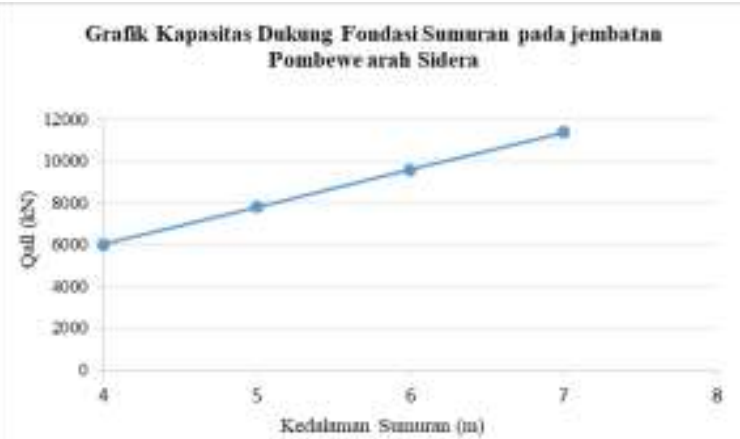

Gambar 3. Grafik Hubungan kedalaman sumuran dengan kapasitas dukung ijin fondasi sumuran pada abutment arah Sidera.

Berdasarkan hasil analisis daya dukung fondasi sumuran pada abutment arah Sidera yang dapat dilihat pada Tabel 3 dan Gambar 3 diperoleh bahwa pada kedalaman 4 nilai daya dukung ijin sebesar $6025.66 \mathrm{KN}$, dengan beban aksial sebesar $8536.52 \mathrm{kN}$, hal ini menunjukkan bahwa nilai daya dukung fondasi masih relatif aman apabila menggunakan kedalaman $4 \mathrm{~m}, 5 \mathrm{~m}$ dan $6 \mathrm{~m}$. Hasil ini dapat dijadikan rujukan kedalaman fondasi, sehingga bisa lebih efektif dari segi biaya dan waktu pelaksanaan dibandingan kedalaman $7 \mathrm{~m}$.
Tabel 4. Hasil analisis penurunan fondasi sumuran pada abutment Sidera

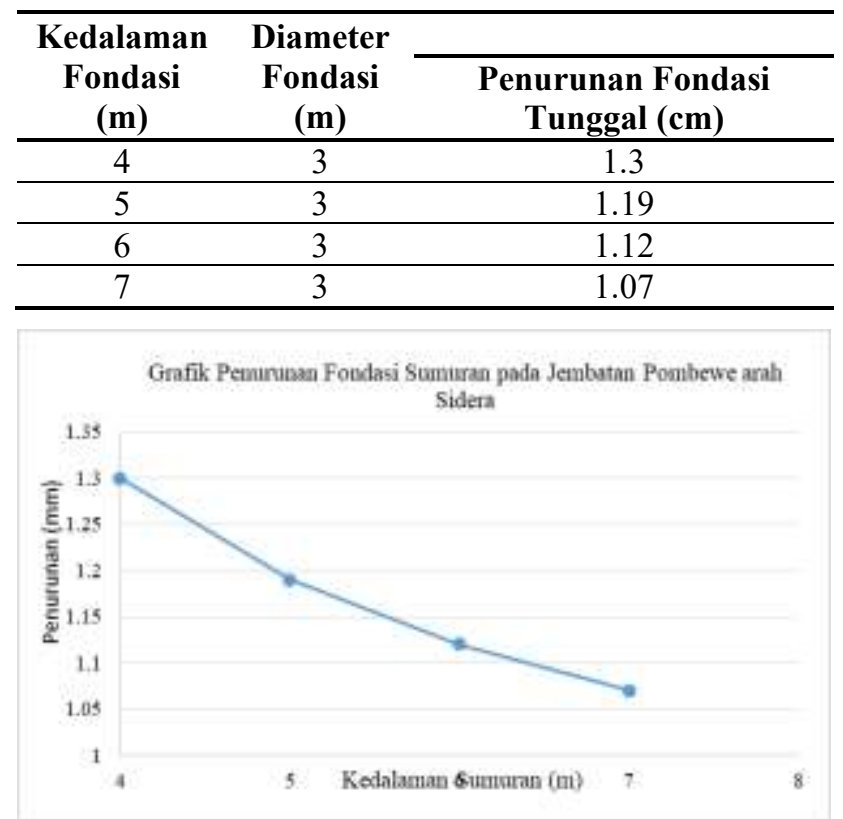

Gambar 4. Grafik Hubungan kedalaman sumuran dengan penurunan fondasi sumuran pada abutment arah Sidera. 
Hasil dari analisis penurunan fondasi sumuran pada abutment Sidera berdasarkan nilai N-SPT dengan kedalaman $4 \mathrm{~m}, 5 \mathrm{~m}, 6 \mathrm{~m}$, dan $7 \mathrm{~m}$ dapat dilihat pada Tabel 4 dan Gambar 4.

Berdasarkan hasil analisis penurunan fondasi sumuran pada abutment arah Sidera yang dapat dilihat pada Tabel 4 dan Gambar 5 diperoleh bahwa pada kedalaman $4 \mathrm{~m}, 5 \mathrm{~m}$ dan $6 \mathrm{~m}$ penurunan fondasi semuran sebesar $1,3-1,12 \mathrm{~cm}$, hal ini menunjukkan bahwa penurunan fondasi sumuran masih memenuhi syarat penurunan maksimum yaitu kurang dari 1 inch $(2,5 \mathrm{~cm})$.

\section{Kesimpulan}

Berdasarkan hasil analisis yang telah dilakukan, dapat disimpulkan beberapa hal sebagai berikut:

1) Hasil analisis dengan menggunakan nilai N-SPT pada kedalaman $4 \mathrm{~m}$ didapatkan nilai daya dukung ijin fondasi sumuran sebesar $6025.66 \mathrm{kN}$, kedalaman $5 \mathrm{~m}$ nilai daya dukung ijin fondasi sumuran sebesar 7811,29 $\mathrm{kN}$, kedalaman $6 \mathrm{~m}$ nilai daya dukung ijin fondasi sumuran sebesar $9601.1 \mathrm{kN}$ dan kedalaman $7 \mathrm{~m}$ nilai daya dukung ijin fondasi sumuran sebesar $11390.9 \mathrm{kN}$ dengan beban aksial sebesar 8536.52.

2) Hasil perhitungan menggunakan parameter tanah pada kedalaman $7 \mathrm{~m}$ dilapangan didapatkan nilai kestabilan terhadap geser $\left(\mathrm{SF}_{\text {geser }}\right)$ sebesar $3.687>1.5$, nilai kestabilan terhadap guling ( $\mathrm{SF}_{\text {guling }}$ ) sebesar $2.0 \geq 2$, dan nilai kestabilan terhadap daya dukung tanah $\left(\mathrm{SF}_{\mathrm{f}}\right)$ sebesar4.5622 > 3. Hasil perhitungan menggunakan metode N-SPT pada kedalaman $4 \mathrm{~m}$ didapatkan nilai Stabilitas pondasi terhadap beban vertikal $(\mathrm{Pv})$ dan momen (M) pada abutment arah Sidera didapatkan Pv $\max =5739.667 \mathrm{kN}$ dan $\mathrm{Pv} \min =3399.733 \mathrm{kN}$, dengan syarat $0<\mathrm{Pv} \min <\mathrm{Pv} \max <\mathrm{Qu}$ dan dari hasil perhitungan stabilitas pondasi terhadap beban horizontal (H) pada abutment arah Sideradidapatkan $\Sigma \mathrm{H}=$ $7662.117 \mathrm{kN}>$ Beban $\mathrm{H}$ yang bekerja di sepanjang abutment $(\Sigma \mathrm{Ty})=7662.117 \mathrm{kN}$.

3) Hasil perhitungan digunakan fondasi sumuran dengan diameter $\mathrm{D}=3 \mathrm{~m}$ dan kedalaman $\mathrm{L}=4 \mathrm{~m}$, diperoleh penurunan tiang tunggal sebesar $\mathrm{S}=130.008 \mathrm{~mm}<250$ mm (penurunan yang di izinkan).

\section{Daftar Pustaka}

[1] D.R. Somaini, "Parametric Study on Soil-Structure Interaction of Bridges with Shallow Foundations", In: Proceedings of the 8th World Conference on Earthquake Engineering. vol. 3, p. 785, 1984.

[2] C.C. Spyrakos, "Assessment of SSI on the Longitudinal Seismic Response of Short Span Bridges”, Engineering Structures, vpl. 12 no. 1, p. 60, 1984.

[3] M. Ciampoli, and P. Pinto, "Effects of Soil-Structure Interaction on Inelastic Seismic Response of Bridge Piers", Journal of Structural Engineering, vol. 121 no. 5, p. 806, 1995

[4] M.A. Saadeghvaziri, A.R. Yazdani-Motlagh, and S. Rashidi, "Effects of Soil-Structure Interaction on
Longitudinal Seismic Response of MSSS Bridges", Soil Dynamics and Earthquake Engineering, vol. 20 no. $1-4$, p. $231,2000$.

[5] A.G. Vlassis, and C.C. Spyrakos, "Seismically Isolated Bridge Piers on Shallow Soil Stratum with Soil-Structure Interaction", Computers \& Structures, vol. 79, no. 32, p. 2847, 2001.

[6] S.E.A. Raheem, T. Hayashikawa, and I. Hashimoto, "Effects of Soil-Foundation-Superstructure Interaction on Seismic Response of Cable-stayed Bridges Tower with Spread Footing Foundation", Journal of Structural Engineering, vol. 49, no. 2, p. 475, 2003.

[7] J.S. Chiou, Y.Y. Ko, S.Y. Hsu, and Y.C. Tsai, "Testing and Analysis of Laterally Loaded Bridge Caisson Foundation in Gravel", The Japanese Geotechnical Society Soils and Foundation. vol. 52, no. 3, p. 562, 2012 .

[8] M.G. Aswathy, and B. Jacob, "Seismic Analysis of Caisson Foundation", International Journal of Engineering Research and Technology, vol. 4, no. 10, p. $560,2015$.

[9] H.J. Struyk, V. der Veen, K.H.C.W, and Soemargono, Jembatan, Jakarta: Pradnya Paramita, 1995.

[10] H.C. Hardiyatmo, Analisis dan Perancangan Fondasi I Edisi Ketiga, Yogyakarta: Gadjah Mada University Press, 2017.

[11] W.C. Teng, Fondation Desigh, New York: PrenticeHall, 1992.

[12] G.G. Meyerhof, "Bearing Capacity and Settlement of Pile Foundations", ASCE Journal of Geotechnical Engineering Division, vol. 5, no. 102, p. 197, 1976.

[13] H.S. Sardjono, Pondasi Tiang Pancang Jilid I, Surabaya: Penerbit Sinar Jaya Wijaya, 1988.

[14] SNI 1725, Pembebanan Untuk Jembatan, Jakarta: Badan Standarisasi Nasional, 2016.

[15] SNI 2833, Perencanaan Jembatan Terhadap Beban Gempa Jakarta, Jakarta: Badan Standarisasi Nasional, 2016.

[16] SNI 2847, Persyaratan Beton Struktural Untuk Bangunan Gedung Jakarta, Jakarta: Badan Standarisasi Nasional, 2013.

[17] SNI 2833, Standart Perencanaan Ketahanan Gempa untuk Jembatan, Jakarta: Badan Standarisasi Nasional, 2008. 
This page is intentionally left blank 